\title{
Tingkat Pengetahuan Ibu Bekerja dalam Pemberian Asi Berhubungan dengan Kejadian ISPA pada Bayi Usia $\leq 1$ Tahun di Desa Bedewang Kecamatan Songgon Banyuwangi Tahun 2017
}

\author{
Ayuk Naimah
}

Universitas Bakti Indonesia Banyuwangi e-mail: ayuknaimah@gmail.com

\begin{abstract}
Abstrak
Beberapa faktor risiko yang dapat menyebabkan ISPA adalah menyelimuti berlebihan, pemberian makanan tambahan terlalu dini, kurangnya pemberian ASI, imunisasi, polusi udara, tempat tinggal yang padat, kurangnya ventilasi dan sosial ekonomi. Desain penelitian ini adalah analitik survey sampai peneliti memenuhi target yang diinginkan dalam waktu satu bulan secara bertahap dengan menyebarkan kuesioner pada 35 responden. Subyek yang diteliti ditarik dari populasi dengan cara Teknik pengambilan sampel dalam penelitian menggunakan total sampling. Penelitian ini dilakukan pada bulan September 2017 yang ditabulasi silang diperoleh hasil hampir seluruhnya responden tingkat pengetahuan kurang sejumlah 32 responden (91.4\%) terjadi ISPA, dan sebagian kecil responden tingkat pengetahuan cukup sejumlah 3 responden $(8.6 \%)$ tidak terjadi ISPA. Analisis data dengan menggunakan uji Krusskal Wallis didapatkan interprestasi hasil Pearson's $R=1.000$, sehingga dibanding dengan Krusskal-Wallis Correlation $=1.000$. Dari hasil data tersebut dikatakan ada hubungan jika Pearson's $R=$ KruskalWallis Correlation maka $\mathrm{H} 1$ diterima. Setelah dilakukan perhitungan menggunakan SPSS maka didapatkan hubungan koefisien korelasi 0,80 - 1,000 korelasi sangat kuat. Kesimpulan dari penelitian ini bahwa tingkat pengetahuan ibu bekerja dalam pemberian ASI dengan kejadian ISPA pada bayi usia $\leq 1$ tahun berhubung sangat kuat. Pada ibu bekerja tingkat pengetahuan dalam pemberian ASI kurang maka akan terjadi ISPA. Dalam pemberian ASI pada waktu ibu bekerja tidak dapat dijadikan alasan untuk tidak memberikan ASI pada bayinya, banyak upaya yang dapat dilakukan oleh ibu dan yang terpenting adalah perubahan pikiran serta komitmen sebagai orang tua untuk mengutamakan kesehatan dan tumbuh kembang pada bayinya.
\end{abstract}

Kata Kunci : Kejadian ISPA, Pengetahuan Ibu Bekerja, Pemberian ASI

Abstract
Some risk factors that may cause acute respiratory tract infections was enveloped exaggerated, supplementary feeding too early, lack of breast feeding, immunization, air pollution, density of housing, inadequate ventilation, and socio-economic. The design of this study using analytic survey research to meet the desired target within a month gradually by distributing questionnaires to 35 respondents. Subjects were drawn from the population studied by means of sampling technique in studies using total sampling. Based on research conducted in September 2017 cross tabulated the results obtained almost entirely lacking a level of knowledge respondents 32 respondents (91.4\%) occurred acute respiratory tract infections, and a small proportion of respondents level of knowledge sufficient number of 3 respondents (8.6\%) did not occur acute respiratory tract infections. Analysis of the data using Krusskal Wallis test interpretation results obtained Pearson's $R=1.000$, so that compared with Krusskal-Wallis Correlation $=1.000$. From the results of the data is said to be no relationship if Pearson's $R=$ Kruskal-Wallis Correlation then $\mathrm{H} 1$ is accepted. Once the calculation is done using the SPSS correlation coefficient obtained relationship 0.80 to 1.000 correlation is very strong. The conclusion of this study that the level of knowledge in breastfeeding working mothers with acute respiratory tract infections incidence in infants aged $\leq 1$ year since very strong. At the working level of knowledge in the mother breast feeding less there will be a respiratory infection. In breastfeeding mothers at work is not an excuse to not give breast milk to their babies, many solutions offered to continue breastfeeding, and the most important thing here is the change in mindset and commitment as parents are always concerned with the health and development of the baby.

Key Words : Genesis of Acute Respiratory Tract Infections, Knowledge Working Mom, Breastfeeding In

\section{Pendahuluan}

Pengetahuan tentang memberikan ASI dengan benar yang beredar di masyarakat diperlukan pemahaman yang mendalam tentang manfaat dan tehnik pemberian ASI. Masih banyak masyarakat (ibu) yang suka mengganti ASI dengan susu formula, padahal ASI mempunyai manfaat yang sangat besar. Menurut Abdullah, (2008) menjelaskan pengetahuan orang tua tentang kejadian ISPA pada bayinya yaitu : "Kejadian ISPA erat terkait dengan pengetahuan orangtua tentang
ISPA, karena orangtua sebagai penanggungjawab utama dalam pemeliharaan kesejahteraan anak. Pada masa bayi masih sangat tergantung pada orangtua. Karena itu diperlukan adanya penyebaran informasi kepada orangtua mengenai ISPA agar orangtua dapat menyikapi lebih dini segala hal-hal yang berkaitan dengan ISPA".

Namun permasalahan pemberian ASI saat ini masih sangat rendah. Rendahnya pemberian ASI disebabkan karena rendahnya pengetahuan ibu tentang pentingnya 
pemberian ASI, penjualan susu formula, faktor sosial-ekonomi. Pemberian MP-ASI terlalu dini juga menjadi faktor penyebabnya. Ibu yang bekerja di sektor formal kesulitan memberikan ASI kepada bayinya karena tidak tersedianya fasilitas dan terbatasnya waktu pemberian ASI untuk menyusui di tempat kerja. Hal ini yang memicu ibu bekerja beralih memberikan bayinya dengan susu formula (Depkes RI, 2011). Lebih lanjut lagi menurut Inayah menjelaskan bahwa permasalahan yang ditimbulkan ibu bekerja dalam pemberian ASI terpaut pada pengetahuan ibu itu sendiri yaitu : "Pendidikan kesehatan terhadap ibu telah dilakukan dalam program promosi kesehatan namun pengetahuan pemberian ASI ternyata masih rendah. Kurangnya perawatan pribadi dan tepat waktu termasuk menyusui jarang dialami oleh bayi yang lahir dari ibu yang bekerja telah dilaporkan meningkatkan kemungkinan kematian neonatal (inayah,2013)".

Bukti penelitian menunjukkan bahawa ASI dapat memberikan perlindungan kepada bayi usia $0-4$ bulan sebanyak $39,8 \%$ terhadap infeksi saluran pernafasan akut. ASI berperan meningkatkan sigA (antibodi yang berperan penting untuk perlindungan didalam mukosa organ tubuh) pada saluran nafas, sehingga ASI dapat mengurangi angka kesakitan infeksi saluran pernafasan bagian atas. Lebih dalam lagi Rasmaliah menjelaskan permasalahan tertentang pemberian ASI dengan terjadinya terinfeksinya ISPA yaitu : "Infeksi Saluran Pernafasan Akut (ISPA) masih merupakan salah satu masalah kesehatan masyarakat yang utama. Hal ini disebabkan masih tingginya angka kematian karena ISPA, terutama pada bayi dan anak balita setiap tahunnya 4 dari 15 juta perkiraan kematian anak dibawah usia 5 tahun disebabkan oleh ISPA dan sebanyak dua pertiga dari kematian tersebut terjadi pada bayi, (Endah dkk, 2009)".

Faktor risiko penyebab ISPA adalah faktor internal dan eksternal. Faktor internal yaitu umur $<2$ bulan, bayi berat lahir rendah, jenis kelamin laki-laki, gizi buruk, kekurangan vitamin $A$, menyelimuti anak secara berlebihan, pemberian terllau dini MP- ASI, sedangkan faktor eksternalnya yaitu kurangnya pemberian ASI, polusi udara (kebiasaan merokok anggota keluarga di lingkungan balita tinggal), imunisasi, tempat tinggal yang padat, kurang memadainya ventilasi dan sosial ekonomi. Survei WHO pada tahun 2008, diperkirakan kasus baru pneumonia pada anak dengan usia dibawah 5 tahun menunjukkan angka tertinggi pada wilayah Asia Tenggara sebanyak 168.74 juta kasus, sedangkan diurutan kedua wilayah pasifik barat dengan jumlah kasus baru 133.05 juta. Selain itu, Indonesia termasuk dalam 15 besar Negara dengan estimasi tertinggi kasus baru pneumonia klinis. Mayoritas anak yang terkena ISPA terdapat pada kelompok usia 12 - 23 bulan, dengan anak usia 0 - 5 bulan merupakan kelompok marginal yang mengalami ISPA, (WHO, 2008).

Menurut Survei Kesehatan Rumah Tangga tahun 2011, balita meninggal karena pneumonia adalah 5 per 1000 balita per tahun (Depkes RI, 2011). Kejadian ISPA di Provinsi Jawa Timur pada tahun 2011 mencapai 18,45\%. Pada tahun 2012 penyakit infeksi yang menyerang balita adalah Pneumonia $18 \%$, Diare $15 \%$ dan Malaria $8 \%$ dari total bayi yang melahirkan (Depkes Jatim, 2012). Penderita ISPA di Kabupaten Banyuwangi menunjukkan angka yang masih cukup tinggi dari tahun 2011 mencapai 12,1\%, tahun 2012 mencapai 11,54\%, tahun 2013 mencapai $11,97 \%$. Data pemberian ASI eksklusif juga masih sangat rendah yaitu pada tahun 2012 mencapai 9,19\%, tahun 2013 mencapai 9,47\% (Dinkes Kabupaten Banyuwangi, 2013).

Studi pendahuluan sebelumnya peneliti lakukan kepada 10 bayi di Desa Bedewang Kecamatan Songgon menunjukkan 7 bayi yang tidak diberikan ASI 5 diantaranya mengalami penyakit ISPA sedangkan 3 bayi yang diberikan ASI tidak pernah mengalami penyakit ISPA sedangkan. Menurut Alan (2010), upaya untuk menurunkan Angka Kematian Balita yang disebabkan ISPA adalah

"Pemerintah telah membuat suatu kebijaksanaan ISPA secara nasional yaitu diantaranya melalui penemuan kasus ISPA balita sedini mungkin di pelayanan kesehatan dasar, penatalaksanaan kasus dan rujukan, adanya keterpaduan dengan lintas program melalui pendekatan MTBS (Manajemen Terpadu Balita Sakit) di Puskesmas serta penyediaan obat dan peralatan untuk Puskesmas Perawatan dan di daerah terpencil".

Upaya pencegahan ISPA pada bayi melalui imunisasi dan non-imunisasi. Pencegahan non-imunisasi seperti nutrisi, keadaan lingkungan, dan pemberian ASI. Balita dengan gizi buruk yang memilik daya tahan tubuh yang rendah akan lebih mudah terserang ISPA dibandingkan balita dengan gizi yang baik. Bayi yang terpapar asap dengan konsentrasi yang tinggi (rokok dan asap hasil pembakaran bahan bakar untuk memasak) dapat merusak mekanisme pertahanan paru-paru sehingga akan memudahkan timbulnya ISPA. Pemberian ASI eksklusif pada bayi dapat mencegah resiko terhadap penularan penyakit ISPA. 
Immunoglobulin A yang terkandung dalam ASI yang diberikan sedini mungkin dapat meningkatkan antibody di dalam tubuh bayi (Depkes RI, 2008).

Upaya yang dapat dilakukan oleh pemerintah adalah merancang program yang dapat mendukung pemberian ASI di masyarakat melalui penyuluhan kesehatan tentang pentingnya pemberian ASI. Penelitian penunjang program pemberian ASI secara berkelanjutan seperti penelitian tentang kandungan ASI. Keluarga juga dapat mengupayakan dengan menjaga kebersihan dan kesehatan lingkungan, immunisasi lengkap dan pemberian ASI dan perawatan anak dengan infeksi saluran pernafasan akut secara tepat di rumah.

\section{Metode Penelitian}

Jenis penelitian ini adalah Survey Analitik. Populasi dalam penelitian ni adalah semua ibu yang mempunyai bayi usia $\leq 1$ Tahun di Desa Bedewang Kecamatan Songgon Banyuwangi dengan jumlah 35 ibu bayi usia $\leq 1$. Tehnik pengambilan sampel menggunakan total sampling. Sampelnya adalah ibu bekerja di Desa Bedewang Kecamatan Songgon Banyuwangi dengan jumlah 35 ibu bayi usia $\leq 1$. Instrumen yang digunakan dalam penelitian ini adalah kuesioner dan menggunakan tehnik wawancara yang dilakukan peneliti dengan menggunakan alat berupa lembar pertanyaan.

\section{Hasil Dan Pembahasan}

Hasil

Distribusi Responden Berdasarkan Tingkat Pengetahuan Ibu Bekerja Dalam Pemberian ASI Tabel 1. Distribusi Responden Berdasarkan Tingkat Pengetahuan Ibu Bekerja Dalam Pemberian Asi Di Desa Bedewang Kecamatan Songgon Banyuwangi.

\begin{tabular}{l|l|l|l}
\hline No & $\begin{array}{l}\text { Tingkat } \\
\text { Pengetahuan }\end{array}$ & $\begin{array}{l}\text { Frekuensi } \\
(\mathbf{F})\end{array}$ & $\begin{array}{l}\text { Persentase } \\
(\%)\end{array}$ \\
\hline 1 & Baik & 0 & $0 \%$ \\
\hline 2 & Cukup & 3 & $8.6 \%$ \\
\hline 3 & Kurang & 32 & $91.4 \%$ \\
\hline \multicolumn{2}{|l}{ Jumlah } & 35 & 100 \\
\hline
\end{tabular}

Sumber : Data Primer Penelitian 2017

Berdasarkan tabel 1 diatas dapat diketahui bahwa hampir seluruhnya responden tingkat pengetahuan ibu bekerja dalam pemberian ASI dengan kriteria kurang. sejumlah 32 responden (91.4\%) dan sebagian kecil responden tingkat pengetahuan ibu bekerja dalam pemberian ASI dengan kriteria cukup sejumlah 3 responden (8.6\%).

Distribusi Responden Berdasarkan Kejadian ISPA Pada Bayi Usia $\leq 1$ Tahun.

Tabel 2. Distribusi Responden Berdasarkan
Kejadian Ispa Pada Bayi Usia $\leq 1$ Tahun Di Desa Bedewang Kecamatan Songgon Banyuwangi.

\begin{tabular}{l|l|l|l}
\hline No & $\begin{array}{l}\text { Kejadian } \\
\text { ISPA }\end{array}$ & $\begin{array}{l}\text { Frekuensi } \\
\text { (F) }\end{array}$ & $\begin{array}{l}\text { Persentase } \\
(\%)\end{array}$ \\
\hline 1 & $\begin{array}{l}\text { Terjadi } \\
\text { ISPA }\end{array}$ & 32 & $91.4 \%$ \\
\hline 2 & $\begin{array}{l}\text { Tidak } \\
\text { Terjadi } \\
\text { ISPA }\end{array}$ & 3 & $8.6 \%$ \\
\hline \multicolumn{2}{l}{ Jumlah } & 35 & 100 \\
\hline
\end{tabular}

Sumber : Data Primer Penelitian 2017

Berdasarkan tabel 2 diatas dapat diketahui bahwa hampir seluruhnya kejadian ISPA pada bayi usia $\leq 1$ tahun dengan kriteria terjadi ISPA sejumlah 32 bayi (91.4\%) dan sebagian kecil kejadian ISPA pada bayi usia $\leq 1$ tahun dengan kriteria tidak terjadi ISPA sejumlah 3

bayi $(8.6 \%)$.

Hubungan Tingkat Pengetahuan Ibu Bekerja Dalam Pemberian ASI Dengan Kejadian ISPA Pada Bayi Usia $\leq 1$ Tahun di Desa Bedewang Kecamatan Songgon Banyuwangi.

Tabel 3. Tabulasi Silang Tingkat Pengetahuan lbu Bekerja Dalam Pemberian Asi Dengan Kejadian Ispa Pada Bayi Usia $\leq 1$ Tahun Di Desa Bedewang Kecamatan Songgon Banyuwangi.

\begin{tabular}{|c|c|c|c|c|c|c|}
\hline \multirow[b]{2}{*}{$\begin{array}{l}\text { Tingkat } \\
\text { Pengetahuan }\end{array}$} & \multicolumn{2}{|c|}{ Terjadi ISPA } & \multicolumn{2}{|c|}{$\begin{array}{l}\text { Thdak Terjadi } \\
\text { ISPA }\end{array}$} & \multicolumn{2}{|c|}{ Total } \\
\hline & $\mathbf{N}$ & $\%$ & $\mathrm{~N}$ & 96 & $\mathbf{N}$ & $\%$ \\
\hline Baik. & 0 & $0 \%$ & 0 & 0 & 0 & 0 \\
\hline Cukup & 0 & $0 \%$ & 3 & $8.6 \%$ & 3 & $\begin{array}{l}8.6 \\
\%\end{array}$ \\
\hline Kurang & 32 & $\begin{array}{l}91.4 \\
\%\end{array}$ & 0 & $0 \%$ & 32 & $\begin{array}{l}91,4 \\
\%\end{array}$ \\
\hline Jumalah & 32 & $\begin{array}{l}91.4 \\
\%\end{array}$ & 3 & $8.6 \%$ & 35 & $\begin{array}{l}100 \\
\%\end{array}$ \\
\hline
\end{tabular}

Sumber : Data Primer Penelitian 2017

Berdasarkan Tabel 3 yang ditabulasi silang diperoleh hasil tingkat pengetahuan ibu bekerja

dalam pemberian ASI dengan kejadian ISPA pada bayi usia $\leq 1$ tahun adalah hampir seluruhnya responden tingkat pengetahuan kurang sejumlah 32 responden $(91.4 \%)$ terjadi ISPA, dan sebagian kecil responden tingkat pengetahuan cukup sejumlah 3 responden $(8.6 \%)$ tidak terjadi ISPA.

Menganalisa hubungan tingkat pengetahuan ibu bekerja dalam pemberian ASI dengan kejadian ISPA pada bayi usia $\leq 1$ tahun di Desa Bedewang Kecamatan Songgon Banyuwangi.

Tabel 4. Analisa Statistik Menggunakan Uji Kruskal Wallis Hubungan Tingkat Pengetahuan Ibu Bekerja Dalam Pemberian Asi Dengan Kejadian Ispa Pada Bayi Usia $\leq 1$ Tahun Di Desa Bedewang Kecamatan Songgon Banyuwangi. 


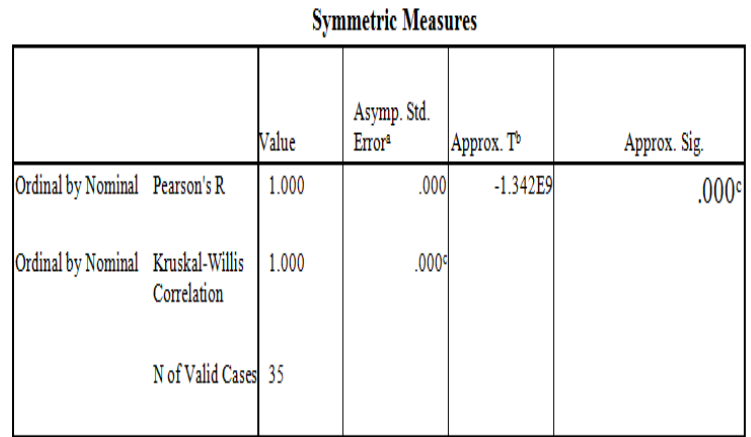

Sumber : Data Primer Penelitian 2017

Berdasarkan Tabel 4 analisis statistik dengan menggunakan uji Krusskal Wallis didapatkan interprestasi hasil Pearson's $R=1.000$, sehingga dibanding dengan Krusskal-Wallis Correlation $=1.000$. Dari hasil data tersebut dikatakan ada hubungan jika Pearson's $\mathrm{R}=$ Kruskal-Wallis Correlation maka $\mathrm{H} 1$ diterima. Setelah dilakukan perhitungan mengguna SPSS versi 17.0 maka didapat nilai Sig $=0,000$, dari hasil penelitian tersebut hubungan tingkat pengetahuan ibu bekerja dalam pemberian ASI dengan kejadian ISPA pada bayi usia $\leq 1$ tahun dengan koefisien korelasi 0,80-1,000 korelasi sangat kuat. Hal ini mempunyai arti bahwa ada hubungan korelasi sangat kuat (signifikan) hubungan tingkat pengetahuan ibu bekerja dalam pemberian ASI dengan kejadian ISPA pada bayi usia $\leq 1$ tahun.

Pembahasan

1Tingkat Pengetahuan Ibu Bekerja Dalam Pemberian ASI

Berdasarkan tabel 4.5 dapat diketahui bahwa hampir seluruhnya responden tingkat pengetahuan ibu bekerja dalam pemberian ASI dengan kriteria kurang sejumlah 32 responden (91.4\%) dan sebagian kecil responden tingkat pengetahuan ibu bekerja dalam pemberian ASI dengan kriteria cukup sejumlah 3 responden (8.6\%). Menurut Wawan dan Dwi, (2010) faktor yang mempengaruhi pengetahuan adalah faktor pendidikan, usia dan pekerjaan seseorang, pengetahuan erat hubungannya dengan pendidikan dimana dengan pendidikan yang tinggi maka orang akan semakin luas pula pengetahuannya. Akan tetapi perlu ditekankan, bukan berarti seseorang yang berpendidikan rendah mutlak berpengetahuan rendah sedangkan pekerjan seseorang yang mapan akan berpengetahuan baik dan juga usia seorang semakin matang usia seorang semakin baik pula tentang pengetahuannya". Selanjutnya menurut Notoatmodjo (2007) lebih diperjelas lagi bahwa faktor yang mempengaruhi pengetahuan adalah "Salah satu bentuk objek kesehatan dapat dijabarkan oleh pengetahuan yang diperoleh dari pengalaman sendiri semakin banyak pengalaman seseorang semakin baik pengetahuan tentang kesehatannya".

Tingkat pengetahuan dipengaruhi oleh faktor umur, pendidikan dan pekerjaan. Hal ini dilihat dari data umum responden sebagian besar responden berumur 25 - 35 tahun sejumlah 23 responden namun pada usia tertentu akan terjadi suatu penurunan ini terjadi akibat peningkatan lemak, penurunan elastisitas otot dan penurunan daya ingat seseorang, sebaliknya usia yang kurang akan menghambat perkembangan sikap seseorang terhadap nilai-nilai yang baru dikenalnya, sehingga dapat menghambat perkembangan sikap seseorang terhadap nilai-nilai yang baru diperkenalnya. Oleh karena itu pengetahuan ibu bekerja dalam pemberian ASI hampir seluruhnya berpengetahuan kurang dikarena kurangnya informasi sehingga pemberian ASI pada bayinya tidak diperhatikan betul sehingga banyak ibu - ibu yang menggantinya dengan susu formula.

Tingkat pendidikan mempengaruhi seseorang memahami pengetahuan yang didapatnya, semakin tinggi pendidikan maka semakin baik pula pengetahuanya. Informasi mempengaruhi pengetahuan seseorang. Hampir setengahnya responden berpendidikan rendah / SD, pengetahuan berhubungan dengan pendidikan sehingga orang dengan pendidikan tinggi maka akan semakin luas pengetahuannya. Kebanyakan seseorang yang berpendidikan rendah pemikirannya juga kurang maksimal sehingga dalam perawatan bayinya juga banyak mengalami hambatan, khususnya dalam pemberian $\mathrm{ASI}$, mereka beranggapan bahwa susu formula sangat baik buat perkembangan dan pertumbuhan bayi dan mereka tidak mengetahui efek samping dari susu formula yang dapat menyebabkan terjadinya ISPA. Begitu juga dengan pekerjaan seseorang hampir setengahnya bekerja sebagai tani dan swasta, sehingga dalam pemberian ASI juga banyak hambatan dan kendala dikarenakan pekerjaan sebagai tani dan sangat riskan atau sulit dalam pemberian ASI dikarenakan keseharian mereka bekerja dibawah terik sinar matahari, dalam pemberian ASI hanya pada waktu mereka berada dirumah sehingga pengetahuan ibu sebatas kurang tentang manfaat ASI pada bayi sehingga bayi di wilayah Desa Bedewang hampir seluruhnya terjadi ISPA.

Kejadian ISPA Pada Bayi Usia $\leq 1$ Tahun

Dari hasil penelitian yang telah dilakukan di Desa Bedewang Kecamatan Songgon Banyuwangi Berdasarkan tabel 4.6 dapat diketahui bahwa hampir seluruhnya kejadian ISPA pada bayi usia $\leq 1$ tahun dengan kriteria terjadi ISPA sejumlah 32 bayi $(91.4 \%)$ dan sebagian kecil kejadian ISPA 
pada bayi usia $\leq 1$ tahun dengan kriteria tidak terjadi ISPA sejumlah 3 bayi (8.6\%).

Menurut (Syahrani dkk, 2012) menjelaskan tentang ISPA sehingga bayi sulit makan adalah : "ISPA merupakan infeksi yang berawal dari saluran pernapasan hidung, tenggorokan, laring, trakea, bronchi dan alveoli. Maka ISPA dapat dikatakan sebagai penyakit infeksi akut yang menyerang salah satu bagian dan atau lebih dari saluran nafas mulai dari hidung (saluran atas) hingga alveoli (saluran bawah) termasuk jaringan adneksanya seperti sinus, rongga telinga tengah dan pleura. ISPA merupakan salah satu alasan yang umum digunakan untuk morbiditas pada bayi sehingga nafsu makan pada bayi menurun dan terganggu". Lebih jauh lagi (setiowati, 2011) menjelaskan tentang faktor terjadinya ISPA pada bayi "Banyak faktor yang mempengaruhi tingginya kejadian ISPA pada anak bayi dan balita yakni faktor intrisik (umur, status gizi, jenis kelamin) dan faktor eksttrinsik (perumahan, sosial ekonomi dan pendidikan). Penelitian diperoleh bahwa umur, kondisi rumah dan kurang mendapatkan ASI, kebiasaan merokok dalam rumah dan adanya kontak dengan penderita ISPA cenderung mempengaruhi kejadian ISPA".

ASI merupakan kebutuhan pokok bagi bayi jika bayi kurang mendapatkan ASI atau sering diganti dengan susu formula maka bayi lebih sering kembung, mual muntah, buang angin, cegukan, rewel, ISPA dan juga dapat mempengaruhi status gizi bayi tersebut. Terjadinya ISPA pada bayi dapat dipengaruhi dari pendidikan ibu dan pekerjaan ibu, pendidikan yang rendah dapat menghambat ibu dalam memperoleh informasi sedangkan pekerjaan yang belum mapan juga dapat mempengaruhi dalam pemenuhan gizi pada bayinya, maka dari itu pemenuhan ASI pada bayinya sangat penting dikarenakan responden berpengetahuan kurang tentang manfaat ASI bagi bayi dengan kurangnya ASI bayi dapat berakibat gangguan jangka panjang pada saluran pencernakan sehingga mengakibatkan daya tahan tubuh berkurang sehingga mudah terserang infeksi terutama ISPA.

Hubungan Tingkat Pengetahuan Ibu Bekerja Dalam Pemberian ASI Dengan Kejadian ISPA Pada Bayi Usia $\leq 1$ Tahun

Dari hasil tabulasi silang tingkat pengetahuan ibu bekerja dalam pemberian ASI dengan kejadian ISPA pada bayi usia $\leq 1$ tahun berdasarkan Tabel diperoleh hasil hampir seluruhnya responden tingkat pengetahuan kurang sejumlah 32 responden (91.4\%) terjadi ISPA, dan sebagian kecil responden tingkat pengetahuan cukup sejumlah 3 responden (8.6\%) tidak terjadi ISPA. Dari uraian tersebut berhubungan sangat kuat tingkat pengetahuan ibu bekerja dalam pemberian ASI dengan kejadian ISPA data di atas dapat ditarik kesimpulan bahwa berhubung sangat kuat jika tingkat pengetahuan ibu dalam pemberian ASI kurang maka akan terjadi ISPA, semua itu di pengaruhi oleh faktor umur, pendidikan dan pekerjaan maka dari itu pendidikan SD lebih baik pemikiran orang yang berpendidikan tinggi, pekerjan juga menjamin status kesehatan bayi jika pekerjaan seseorang tidak mapan maka kesehatan bayi dan anaknya kurang perhatian juga.

Menurut Sugiono yang peneliti analisa menggunakan SPSS dan hitungan rumus uji Spearman's rho mendapat hasil sebagai berikut : "Dalam hasil analisis statistik dengan menggunakan uji Krusskal Wallis didapatkan interprestasi hasil Pearson's $R=1.000$, sehingga dibanding dengan Krusskal-Wallis Correlation $=1.000$. Dari hasil data tersebut dikatakan ada hubungan jika Pearson's $R=$ Kruskal-Wallis Correlation maka $\mathrm{H} 1$ diterima. Setelah dilakukan perhitungan mengguna SPSS versi 17.0 maka didapat nilai Sig = 0,000 , dari hasil penelitian tersebut hubungan tingkat pengetahuan ibu bekerja dalam pemberian ASI dengan kejadian ISPA pada bayi usia $\leq 1$ tahun dengan koefisien korelasi $0,80-1,000$ korelasi sangat kuat. Hal ini mempunyai arti bahwa ada hubungan korelasi sangat kuat (signifikan) hubungan tingkat pengetahuan ibu bekerja dalam pemberian ASI dengan kejadian ISPA pada bayi usia $\leq 1$ tahun, (Sugiarti,eni 2011). Dari pendapat diatas peneliti dapat menyimpulkan bahwa hal ini mempunyai arti bahwa ada hubungan yang sangat kuat (Signifikan) hubungan tingkat pengetahuan ibu bekerja dalam pemberian ASI Dengan kejadian ISPA pada bayi usia $\leq 1$ tahun dikarenakan dari 35 responden tingkat pengetahuan ibu bekerja dalam pemberian ASI dengan kejadian ISPA pada bayi usia $\leq 1$ tahun adalah hampir seluruhnya responden tingkat pengetahuan kurang sejumlah 32 responden (91.4\%) terjadi ISPA semua itu dipengaruhi oleh umur, pendidikan responden sebatas SDdan pekerjaan tani dan swasta. berdasarkan tabel 4.2 dapat diketahui bahwa sebagian besar responden berumur 25 - 35 tahun sejumlah 23 responden (65.7\%). Pada usia tertentu akan terjadi suatu penurunan ini terjadi akibat peningkatan jumlah lemak, penurunan elastisitas otot dan penurunan daya ingat seseorang.

Berdasarkan tabel 4.3 dapat diketahui hampir setengah responden berpendidikan SD sejumlah 14 responden (40\%). Pendidikan 
responden sebatas SD karena pemikiran pendidikan rendah karena sebatas kemampuan yang mereka miliki. Berdasarkan tabel 4.4 dapat diketahui bahwa hampir setengah responden bekerja sebagai tani dan swasta sejumlah 17 responden (48.6\%). Semua itu bisa disebabkan karena peran tingkat pengetahuan ibu bekerja dalam pemberian ASI sebagai penunjang terjadi ISPA dikarenakan kurangnya asupan ASI sehingga bayi sering mengalami ISPA. Selain itu kurangnya informasi dan tidak pernah mengikuti penyuluhan tentang kesehatan dapat menghambat pengetahuan seseorang. Dari fonemena diatas peneliti menarik kesimpulan bayi kekurangan ASI bisa terjadi ISPA, orang tua perlu mengetaui manfaat ASI yaitu menurunkan risiko terjadinya penyakit infeksi, misalnya infeksi pada saluran pernafasan. Dalam pemberian ASI pada waktu ibu bekerja bukan alasan untuk tidak memberikan ASI pada bayinya.

\section{Kesimpulan Dan Saran}

Dari hasil analisis statistik dengan menggunakan uji Krusskal Wallis didapatkan interprestasi hasil Pearson's $R=1.000$, sehingga dibanding dengan Krusskal-Wallis Correlation $=1.000$. Dari hasil tersebut dapat dikatakan ada hubungan jika Pearson's $\mathrm{R}=$ Kruskal-Wallis Correlation maka $\mathrm{H} 1$ diterima. Setelah dilakukan perhitungan mengguna SPSS versi 17.0 maka didapat nilai Sig $=$ 0,000 , dari hasil penelitian tersebut hubungan tingkat pengetahuan ibu bekerja dalam pemberian ASI dengan kejadian ISPA pada bayi usia $\leq 1$ tahun dengan koefisien korelasi $0,80-1,000$ korelasi sangat kuat. Banyak upaya yang dapat dilakukan oleh ibu dan yang terpenting adalah perubahan pikiran serta komitmen sebagai orang tua untuk mengutamakan kesehatan dan tumbuh kembang pada bayinya.

\section{Daftar Pustaka}

Abdullah. 2008. Pengaruh Pemberian ASI Terhadap Kasus ISPA pada Bayi Umur 04 Bulan. Jakarta: UI

Allen \& Marotz. (2010). Perkembangan Anak Prakelahiran Hingga Usia 12 Tahun. Di Terjemahkan Oleh Valentino. Jakarta: PT Indeks.

Depkes

$\mathrm{RI}$,

2011. http://www.depkes.go.id/downloads/advert orial/adv_pp_asi.pdf diakses pada tanggal 2 Agustus 2017 pukul 20.05.

Departemen Kesehatan RI. 2011. Pneumonia Penyebab Kematian. Dari : www.depkes.go.id

Departemen Kesehatan Jatim . 2012. Data kasus Pneumonia Anak .

Data Dinas Kesehatan Banyuwangi 20122013 Tentang ASI Esklusif

Endah PN, Daroham dan Mutiatikum. (2009). Penyakit ISPA hasil RISKESDAS di Indonesia. Bulletin Penelitian Kesehatan Supplement $2009: 50-55$

Notoatmodjo S. 2007b. Promosi Kesehatan dan Ilmu Perilaku. Jakarta: Rineka Cipta.

Inayah, Abdllah. (2013) Determinan Perilaku Pemberian Air Susu Ibu Esklusif Pada Ibu Pekerja. Jurnal kesehatan Masyarakat Nasional, 7 (7), 298-303

Sugiarti, Eni. (2011). Faktor- faktor yang Berhubungan Dengan Pemberian ASI Esklusif di Kecamatan Karang Malang Kabupaten Sragen. Jurnal Kesehatan, 4 (2), 195-206

Setiowati, Tri.(2011). Hubungan Faktor- faktor Ibu Dengan Pelaksanaan Pemberian ASI Esklusif pada Bayi Usia 6- 12 Bulan. Jurnal Kesehatan 2.

Syahrani, Santoso dan Sayono. (2012). Pengaruh Pendidikan Kesehatan Tentang Pelaksanaan ISPA Terhadap Pengetahuan dan Keterampilan Ibu Dalam Merawat Anak Dengan ISPA di rumah. Di akses 15 juni 201709.00 WIB

WHO. 2008.2 Pneumonia. http://www.who.int/en/. Diakses tanggal 17 Maret 2017 pukul 21.00 WIB. 